\title{
INFLUENCE OF NITROGEN NUTRITION ON THE AMOUNT OF HORDEIN, PROTEIN $Z$ AND $\beta$-AMYLASE MESSENGER RNA IN DEVELOPING ENDOSPERMS OF BARLEY
}

\author{
by \\ HENRIETTE GIESE") and H. ESTEBAN HOPP ${ }^{21}$ \\ Department of Physiology, Carlsberg Laboratory, Gamle Carlsberg Vej 10, \\ DK-2500 Copenhagen Valby \\ and \\ Agricultural Research Department, Risø National Laboratory, \\ DK-4000 Roskilde \\ "Present address: Botanisches Institut der Universität Kiel, \\ Olshausenstrasse 40-60, Biologiezentrum, D-2300 Kiel, F.R.G. \\ ") Fellow of the Consejo Nacional de Investigaciones Cientificas \\ y Técnicas, present address: Departamento de Genética INTA, \\ CC 25, 1712 Castelar, República Argentina.
}

Keywords: Hordeum vulgare L. cv. Bomi, mutant Risø 56, cDNA, storage proteins, molecular hybridization, liquid culture of spikes, prolamin, grain filling, high-lysine mutant, albumin, lysine-rich proteins, immunoaffinity isolation, in vitro protein synthesis

The amount of mRNA encoding hordein, protein $Z$ and $\beta$-amylase was analyzed in developing endosperms of the barley variety Bomi and the high-lysine mutant Risø 56. Spikes were cultured in liquid media containing different amounts of ammonium nitrate and endosperms harvested between 15 and 25 days after anthesis. Levels of mRNA were determined by in vitro translations. In addition, $B$ hordein and protein $Z$ mRNA species were titrated by molecular hybridization to cDNAs encoding B hordein and protein $Z$ polypeptides, respectively. Increasing amounts of mRNAs were found in response to increasing nitrogen application. The amount of mRNA for $\mathrm{C}$ hordein and protein $\mathrm{Z}$ increased linearly with increasing nitrogen concentrations in the medium, whereas the rise in $\beta$-amylase mRNA was slight. A concentration of $0.5 \mathrm{~g} \times \mathrm{l}^{-1}$ nitrogen stimulated the transcription of $B$ hordein mRNA, but further increases of nitrogen supply up to $2{\mathrm{~g} \times \mathrm{I}^{-1}}^{-}$resulted in little additional B hordein mRNA production. At high nitrogen levels $\mathrm{C}$ hordein and protein $\mathrm{Z}$ mRNA are preferentially transcribed whereby these proteins serve as major nitrogen sinks. Hordein and protein $\mathrm{Z}$ mRNA are effectively augmented by application of nitrogen after the onset of grain filling and storage protein synthesis. Removal of nitrogen in the medium during grain filling led to a short term decrease in the amounts of these mRNAs. Thus it is possible to modulate the mRNA levels by changing the nitrogen concentration in the medium. The absence of mRNA for B hordein polypeptides in the high-lysine mutant Risø 56, (hor $2 \mathrm{ca}$ ), does not influence the effect of nitrogen on the expression of the $\mathrm{C}$ hordein, protein $\mathrm{Z}$ and $\beta$-amylase genes.

Abbreviations: $c D N A=$ DNA complementary to $\mathrm{mRNA}$; $\mathrm{SDS}-\mathrm{PAGE}=$ sodium dodecyl sulphate polyacrylamide gel electrophoresis; $\mathrm{Tm}=$ melting temperature of the DNA 


\section{INTRODUCTION}

Hordein, the lysine poor storage protein of the barley endosperm, is coded for by genes in three loci on chromosome 5, Hor-1, Hor- 2 and Hor-3 $(1,23,37,38,40,41)$. The Hor-1 and the Hor-2 loci consist of a number of closely related genes $(27,33)$ and there are indications that the expression of these genes are under separate regulatory control $(12,30,32)$. It has been suggested that the nutritional quality of barley grains could be improved by increasing other more lysine-rich protein components at the expense of hordein $(9,41)$. The salt-soluble protein fraction contains several lysine rich proteins, notably protein $Z, \beta$-amylase and two protease inhibitors, contributing to about $7 \%$ of the total grain lysine in normal varieties (19). Protein $Z$ contributes up to $5 \%$ of the total grain lysine in normal varieties, and more than $7 \%$ in some high lysine barleys (18). The genes for both proteins, protein $Z$ and $\beta$-amylase have been localized to chromosome 4 (31). The synthesis of protein $Z$ and $\beta$-amylase coincide with that of hordein during grain filling (16). Hordein and $\beta$-amylase are synthesized on the endoplasmic reticulum and hordein is known to be deposited in vacuoles as protein bodies $(3,4,5,6,24)$. Hordein polypeptide synthesis is enhanced when nitrogen fertilization is increased (29). The synthesis of $C$ hordein polypeptides is more accentuated at high nitrogen nutrition than that of $B$ hordein polypeptides $(15,26,29)$ and protein $Z$ has been found to increase in response to nitrogen nutrition in a comparable way (16). It is not known, if this nutritional response of storage protein synthesis is achieved by regulation of transcription or translation of the mRNA or both.

The aim of this study is to analyze the amount of mRNAs encoding hordein, protein $\mathrm{Z}$ and $\beta$-amylase in endosperms which were offered nitrogen at different concentrations during the grain filling period. By culturing detached barley spikes in liquid media containing sucrose and increasing concentrations of ammonium nitrate the nutritional supply of the endosperm could be controlled. The amount of $\beta$-amylase and $C$ hordein mRNAs was monitored by in vitro translation of this RNA, whereas the levels of B hordein and protein $\mathrm{Z}$ mRNAs were estimated by in vitro translation as well as molecular hybridization to cDNAs encoding amino acid sequences of $B$ hordein and protein $Z$, respectively.

The high lysine barley, Risø 56 (hor $2 \mathrm{ca}$ ), carries a mutation close to or at the $B$ hordein locus (8) which causes the absence of B hordein mRNA $(20,28)$. Risø 56 has an increased amount of protein $Z$ and $\beta$-amylase in the endosperms compared to the variety Bomi (14, 18). The amount of mRNA encoding these proteins was determined in order to investigate whether the mutation influences the expression of the $C$ hordein, protein $\mathrm{Z}$ and $\beta$-amylase genes in response to nitrogen nutrition.

\section{MATERIALS AND METHODS}

\subsection{Chemicals}

Escherichia coli DNA polymerase I (Klenow large fragment) and polyadenylic acid were obtained from Boehringer Mannheim (FRG), Poly(U)-Sepharose 4B, protein A Sepharose 4B and SP Sephadex G 50 were from Pharmacia (Sweden). Gene screen hybridization transfer membranes and $\alpha^{32} \mathrm{P}-\mathrm{dATP}\left(800 \mathrm{Ci} \times \mathrm{mmol}^{-1}\right)$ for radioactive labelling of the probes for hybridization were purchased from New England Nuclear (USA). Rabbit reticulocyte lysate and $\mathrm{L}-^{35} \mathrm{~S}-\mathrm{me}-$ thionine $\left(1150 \mathrm{Ci} \mathrm{mmol}^{-1}\right)$ for in vitro translations and poly $\left(5-{ }^{3} \mathrm{H}\right)$-uridylic acid $(20-72$ $\mathrm{Ci} \times \mathrm{mmol}^{-1}$ ) for polyadenylated RNA determination were from Amersham International (UK), X-ray film (X-omat AR) as well as Xomatic regular intensifying screens were from Kodak (USA). Synthetic M13 specific primer for hybridization d(C-A-C-A-A-T-T-C-C-A-CA-C-A-A-C) was obtained from New England Biolabs (USA). Rabbit protein $Z$ antibody was a generous gift from Dr. JøRN HEJGAARD (Department of Biochemistry and Nutrition Technical University of Denmark). Rabbit antibodies reacting with $\beta$-amylase from Sorghum and beer fraction $X$ containing protein $Z$ were kindly supplied by Dr. JOHN MUNDY (Department of Biotechnology, Carlsberg Research Laboratory). Formamide (Merck, FRG) was deionized with Amberlite MB-1 and stored at $-20{ }^{\circ} \mathrm{C}$ until use. Phenol (Merck, FRG) was redistilled and equilibrated with $0.1 \mathrm{M}-\mathrm{Tris}-\mathrm{HCl}$ pH 7.5 and 10 mM-EDTA and kept at $-20^{\circ} \mathrm{C}$ until use. 


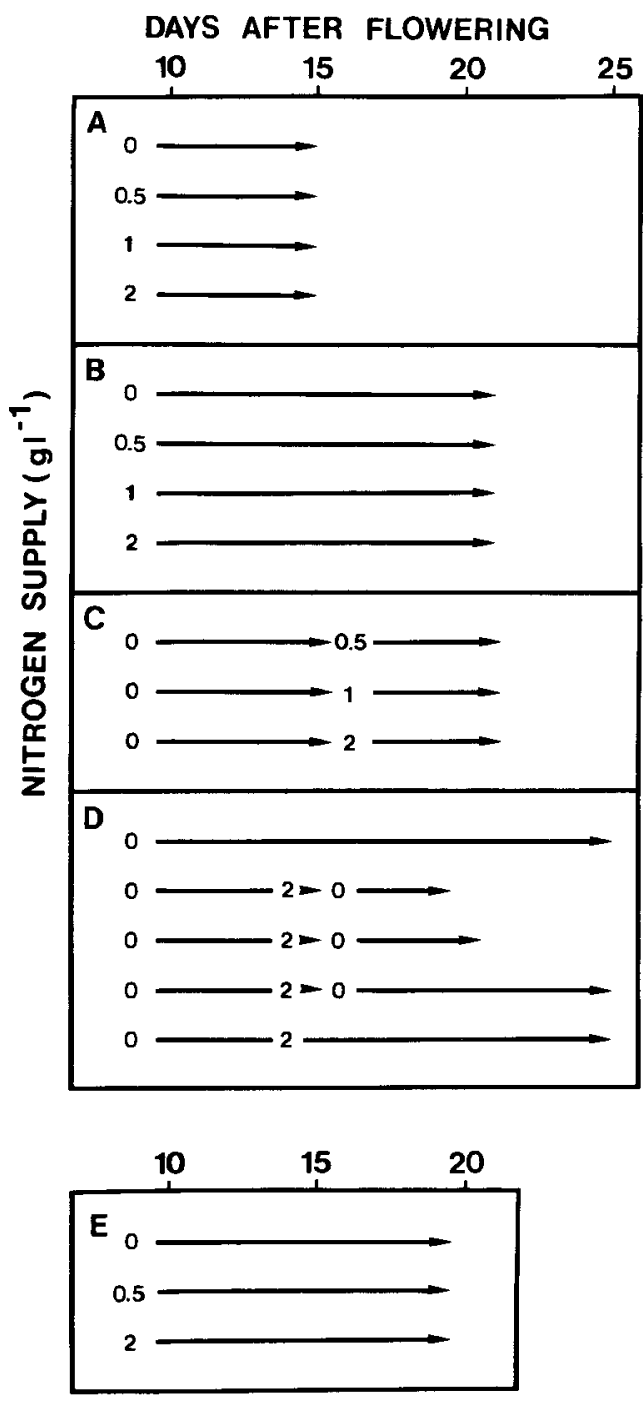

Figure 1. Flow sheets of the experiments with culture of detached spikes on media containing different nitrogen concentrations.

A, B, C and D: Bomi, E: Risø 56. A. Continuous supply of nitrogen at different concentrations from day 8 to 15 after anthesis. B. Continuous supply of nitrogen at different concentrations from day 8 to day 22 after anthesis. C. Supply of nitrogen from day 17 and harvest at day 22 after anthesis. D. Pulse of high nitrogen supply from day 13 to day 16 and controls without nitrogen supply and constant nitrogen from day 13 . E. Continuous supply of nitrogen to mutant Risø 56 heads at different concentrations from day 8 to day 19 after anthesis.

\subsection{Plant material}

The barley genotypes (Hordeum vulgare L.) $\mathrm{cv}$. Bomi and mutant Risø 56 were used. The latter was a recombinant line from a cross of the mutant in Carlsberg II with Bomi (8). The line is free of the unlinked translocation present in the original mutant stock and carries the allele characteristic for the Carlsberg II Hor-1 gene which differs from the Bomi allele by the absence of the uppermost $C$ hordein band after SDSPAGE, cf. Figures 9 vs. 1.

Plants were grown, spikes detached eight days after heading and placed in test tubes for cultivation as described in (11) and (15). The plants of the variety Bomi were grown at a temperature cycle of $18^{\circ} \mathrm{C}-12^{\circ} \mathrm{C}$. The Risø 56 plants were four times exposed to $25^{\circ} \mathrm{C}$ for 24 hours due to a defect cooling system of the growth chamber.

Spikes were cultured in $50 \mathrm{ml}$ of media con-

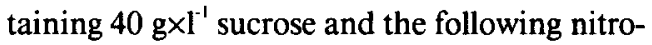
gen concentrations: $0,0.5,1.0$ and $2.0 \mathrm{~g} \mathrm{~N} \times \mathrm{l}^{-1}$ (given as $\mathrm{NH}_{4} \mathrm{NO}_{3}$ ). Flow sheets for the different experiments are presented in Figure 1. Twenty spikes were cultured at each nitrogen level: ten of these spikes were harvested after seven days in culture (Figure 1A) and the remaining ten after 14 days (Figure $1 \mathrm{~B}$ ) in culture (that is 15 and 22 days after anthesis, respectively).

Another 21 spikes were cultured without nitrogen for nine days whereafter groups of seven spikes were transferred to media containing 0.5 ,

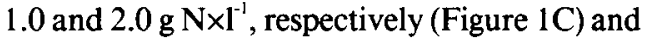
harvested after five days ( 22 days after anthesis).

Finally 25 spikes were placed in media containing no nitrogen (Figure 1D). Five days later 20 of these spikes were transferred to media

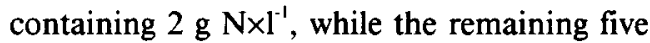
spikes were left in the media without nitrogen until harvest 25 days after anthesis. After three days of growth in the presence of high nitrogen levels 15 of the 20 spikes were returned to their original culture vessels. The remaining five were left in the high nitrogen media until harvest at 25 days after flowering. The 15 spikes were harvested in groups of five at 19,21 and 25 days after anthesis.

Risø 56 spikes were transferred to liquid media with the following concentrations of ni-

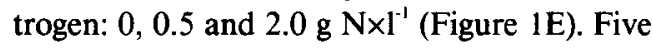
spikes were cultivated at each nitrogen level and 
harvested after 11 days of culture (that is at 19 days after anthesis).

\subsection{Protein analysis}

Ten endosperms from each treatment, selected from different spikes, were examined. The amount of hordein was determined by Kjeldahl nitrogen determination (15). Following the extraction of hordeins (14) the remaining proteins, comprising albumin, globulin and glutelin were extracted with $40 \mathrm{~mm}$-boric acid, $41 \mathrm{~mm}$-Tris, $1 \%$ SDS and 5mM-dithiothreitol ( $\mathrm{pH} \mathrm{8.6)} \mathrm{for} 1$ hour at $50{ }^{\circ} \mathrm{C}$. Samples were dialyzed and prepared for Kjeldahl nitrogen determination and SDS-PAGE as previously described (14). SDS-PAGE separation of the extracted proteins as well as staining of the polypeptides was carried out according to (10).

\subsection{Isolation and translation of endosperm RNA}

RNA extraction and isolation of polyadenylated RNA as well as Poly(U)-Sepharose 4B column chromatography were carried out as described in (3) and (20). Total and polyadenylated RNA were quantified by determination of the absorbance at $260 \mathrm{~nm}$ estimating one O.D. unit to equal $40 \mu \mathrm{g}$ of RNA. The polyadenylated RNA concentration in the total RNA fraction was also estimated by hybridization with ${ }^{3} \mathrm{H}$ polyuridylic acid (3). In vitro translations of polyadenylated RNA were performed according to the protocol of a commercial rabbit reticulocyte lysate preparation. Approximately $2 \mu \mathrm{g}$ of polyadenylated RNA were incubated in the presence of $0.06 \mathrm{mCi} \mathrm{L}^{35} \mathrm{~S}$-methionine and $25 \mu \mathrm{l}$ rabbit reticulocyte lysate for one hour at $30^{\circ} \mathrm{C}$ and hordein extraction was performed on a sample containing $200,000 \mathrm{dpm}$ translation products. Hordein polypeptides were extracted by addition of $55 \%$ 2-propanol (v/v), 2\% 2-mercaptoethanol $(\mathrm{v} / \mathrm{v})$ and $10 \mathrm{mM}-\mathrm{methionine}$ at 60 ${ }^{\circ} \mathrm{C}$ for 30 minutes (3).

Analysis of the in vitro synthesized $\beta$-amylase and protein $\mathrm{Z}$ precursors by immunoprecipitationwas essentially as described in (24). Approximately $2 \mu \mathrm{g}$ of polyadenylated RNA were incubated in the presence of $0.2 \mathrm{mCi} \mathrm{L}^{35} \mathrm{~S}$ methionine $\left(1150 \mathrm{Ci} \mathrm{mmol}^{-1}\right)$ and $75 \mu \mathrm{l}$ of reticulocyte lysate mixture for one hour at $30^{\circ} \mathrm{C}$. Aliquots containing the same incorporated specific counts $\left(1.2 \times 10^{6} \mathrm{cpm}\right)$ were diluted to a total volume of $0.6 \mathrm{ml}$ with $50 \mathrm{~mm}$-Tris $\mathrm{HCl} \mathrm{pH} \mathrm{7.5,}$ $0.15 \mathrm{M}-\mathrm{NaCl}, 10 \mathrm{~mm}$-methionine and $2 \%$ Triton $\mathrm{X}-100$ and incubated at room temperature for 30 minutes. Unspecific binding of proteins to the Sepharose was prevented by a 30 minutes preincubation of the lysate mixture with $0.1 \mathrm{ml}$ hydrated protein A-Sepharose 4B at room temperature under continuous stirring. The suspension was then centrifuged for two minutes in an Eppendorf microfuge. The pellet containing the Sepharose was discarded. The supernatant was combined with $20 \mu \mathrm{l}(0.4 \mathrm{mg}$ protein $)$ preimmune serum and incubated for 1 hour at room temperature under continuous stirring, followed by 30 minutes of incubation in the presence of $50 \mu \mathrm{l}$ of protein A-Sepharose 4B. After centrifugation the resulting supernatant was combined with $40 \mu \mathrm{l}(0.2 \mathrm{mg}$ protein $)$ of $\beta$-amylase antibody and immunoprecipitated as described (24) washed once in $1 \mathrm{ml} \mathrm{50mM-Tris}$ $\mathrm{HCl} \mathrm{pH} 7.5,0.15 \mathrm{M}-\mathrm{NaCl}, 10 \mathrm{~mm}$-methionine and $2 \%$ Triton $\mathrm{X}-100$ and three times in $1 \mathrm{ml}$ $10 \mathrm{~mm}$-Tris $\mathrm{HCl} \mathrm{pH} \mathrm{7.5}$. The supernatant was used for a subsequent immunoaffinity isolation of protein $\mathrm{Z}$ precursors with $0.15 \mathrm{mg}$ protein $\mathrm{Z}$ antibody in the case of Bomi mRNA translation products or $0.3 \mathrm{mg}$ beer fraction $\mathrm{X}$ antibody in the case of Risø $56 \mathrm{mRNA}$ translation products. The incubation conditions, immunoprecipitation and washing were the same as for $\beta$-amylase precursor isolation. Sample preparations of total in vitro translation products, immunoaffinity isolation products and hordein precursor polypeptides were taken up in $20 \mu \mathrm{l} 0.1 \mathrm{M}$-Tris base, $5 \mu 10.1 \mathrm{M}$-dithiotreitol and $10 \mu \mathrm{l}$ of $30 \%$ sucrose, $5 \%$ SDS and $0.25 \%$ bromophenol blue and boiled for 5 minutes. Alkylation of the samples was done by adding $10 \mu \mathrm{l} 0.5 \mathrm{M}$-iodoacetamide for one hour. SDS-PAGE were carried out according to (15). The gels were fixed in $50 \%$ methanol and $10 \%$ acetic acid $(\mathrm{v} / \mathrm{v})$ for two hours, washed several times with $50 \%$ methanol $(\mathrm{v} / \mathrm{v})$ until no acidity was detectable, and processed for fluorography with $1 \mathrm{M}$-salicylic acid in $50 \%$ methanol for 20 minutes with the procedure of Chamberlain (7). The films were exposed for 16 to 72 hours at $-70{ }^{\circ} \mathrm{C}$. 
2.5. Hybridization of $B 1$ hordein and protein $Z$ cDNA probes to mRNA

Hybridizations to barley RNA were carried out with phage M13 DNA probes complementary to the mRNA and containing the cDNA insert present in the recombinant plasmid pc hor2-4 (33) or containing a protein $\mathrm{Z}$ cDNA insert (34). The hordein cDNA has previously been characterized as containing approximately $2 / 3$ of the coding sequence of a $\mathrm{BI}$ hordein polypeptide (33). Protein Z cDNA contains a copy of a mRNA encoding the $N$-terminal part of protein $\mathrm{Z}(34)$. Hybridizations with the $\mathrm{B} 1$ hordein cDNA were carried out at $\mathrm{Tm}=-25^{\circ} \mathrm{C}$ and with the protein $\mathrm{Z} c \mathrm{cNA}$ at $\mathrm{Tm}=-22^{\circ} \mathrm{C}$. Harvesting of phages, purification of single stranded phage DNA and labelling of the probe were essentially as described in $(21,33,35)$. The probe consisted of $100 \mathrm{ng}$ of a ${ }^{32} \mathrm{P}$-labelled M13 recombinant DNA with a specific activity of $10^{8}$ $\mathrm{dpm} \times \mu \mathrm{g}^{-1}$ for the B1 hordein cDNA and $2 \times 10^{8}$ $\mathrm{dpm} \times \mu \mathrm{g}^{-1}$ for the protein $\mathrm{Z}$ cDNA. Gene screen hybridization transfer membranes were soaked in $0.3 \mathrm{M}-\mathrm{NaCl}$ and $0.03 \mathrm{M}-\mathrm{Na}$ citrate and then placed on a microsample filtration manifold from Schleicher \& Schüll (FRG) and air dried under vacuum. RNA samples were then applied and fixed to the filter by baking for 2 hours at 80 ${ }^{\circ} \mathrm{C}$. Hybridization procedures as well as washing of the filter and autoradiography were performed as described in (20).

\section{RESULTS}

3.1. Amount of protein and RNA in endosperms from cultivated spikes

As presented in diagrammatic form in Figure 1 four experiments have been carried out. In the first one (A) nitrogen was supplied at different concentrations from day 8 to day 15 after anthesis. In the second experiment (B) the supply of nitrogen was extended up to 22 days after anthesis. In the third experiment (C) the effect of a late supply of nitrogen (17-22 days after anthesis) was studied. In the final experiment (D) the effect of a nitrogen pulse from day 13 to 16 after anthesis was investigated. The dry weight, amount of protein and RNA of endosperms from spikes cultured under these different conditions are presented in Table $\mathrm{I}$. At the highest nitrogen concentration $\left(2 \mathrm{~g} \mathrm{~N} \mathrm{l}^{-1}\right)$ the hordein is increased by a factor of 2.5 compared

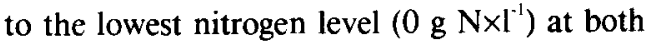
endosperm development stages examined,

Table I.

Effect of different concentrations of nitrogen nutrition on the hordein and RNA content of the developing endosperms in Bomi and mutant Risø 56. Values are given per endosperm at the age indicated in the first column.

\begin{tabular}{|c|c|c|c|c|c|c|}
\hline $\begin{array}{l}\text { Days in } \\
\text { in culture }\end{array}$ & $\begin{array}{l}\text { Nitrogen } \\
\text { supply } \\
\mathrm{g} \times l^{-1}\end{array}$ & $\begin{array}{l}\text { Dry } \\
\text { weight } \\
\text { mg }\end{array}$ & $\begin{array}{l}\text { Hordein N } \\
\text { RNA } \\
\mu \mathrm{g}\end{array}$ & $\begin{array}{l}\text { Non-hordein N } \\
\text { RNA } \\
\mu \mathrm{g}\end{array}$ & $\mu \mathrm{g}$ & Polyadenylated \\
\hline \multirow[t]{2}{*}{ Bomi } & 0 & 13 & 76 & 164 & 32 & 0.59 \\
\hline & 0.5 & 12 & 107 & 138 & 31 & 0.66 \\
\hline \multirow[t]{4}{*}{7 days at } & 1 & 12 & 145 & 192 & 35 & 0.67 \\
\hline & 2 & 14 & 171 & 225 & 38 & 0.74 \\
\hline & 0 & 22 & 184 & 149 & 29 & 0.58 \\
\hline & 0.5 & 24 & 257 & 231 & 33 & 0.66 \\
\hline \multirow[t]{2}{*}{14 days at } & 1 & 18 & 377 & 236 & 34 & 0.66 \\
\hline & 2 & 24 & 468 & 268 & 43 & 0.84 \\
\hline 9 days at & 0.5 & 24 & 245 & 189 & 33 & 0.62 \\
\hline $0 \mathrm{~g} \mathrm{~N} \times \mathrm{I}^{-1}$ & 1 & 22 & 359 & 240 & 35 & 0.63 \\
\hline and 5 days at & 2 & 27 & 483 & 248 & 36 & 0.68 \\
\hline Rise 56 & 0 & 10 & 37 & 58 & 11 & 0.31 \\
\hline \multirow[t]{2}{*}{11 days at } & 0.5 & 12 & 63 & 87 & 14 & 0.31 \\
\hline & 2 & 13 & 83 & 114 & 17 & 0.44 \\
\hline
\end{tabular}


whereas albumin, globulin and glutelin only increase by a factor of 1.5. Application of nitrogen for five days prior to harvest results in a protein deposition comparable to that of spikes receiving a constant nitrogen supply from the start of the culture.

Slightly more total and polyadenylated RNA was found in the endosperms cultured at the highest nitrogen concentrations, indicating that nitrogen application does not have the same dramatic effect on the amount of RNA as on the amount of proteins.

Twice the amount of hordein as well as albumin, globulin and glutelin is accumulated in Risø 56 endosperms when nitrogen was raised

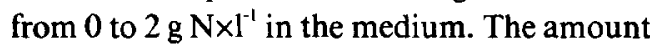
of albumin, globulin and glutelin is higher than the amount of hordein at all nitrogen levels. The dry weight of Risø 56 endosperms at 19 days after anthesis is comparable to the 15 days old Bomi endosperms. However, only half the amount of protein and RNA is present in Risø 56 endosperms when compared to that of Bomi. This difference may be due to different growing conditions of the Risø 56 and Bomi plants prior to the transfer of spikes to liquid culture.

\subsection{The effect of continuous and late supply of nitrogen}

All hordein polypeptides in Bomi endosperms increase with increasing concentrations of nitrogen in the medium. High amounts of nitrogen (1 or $2 \mathrm{~g} \mathrm{~N} \times 1^{-1}$ ) led to a preferential accumulation of the $C$ hordein polypeptides compared to the $B$ hordein polypeptides (Figure 2A, tracks 3 and 4, Figure 2B, tracks 7 and 8). At high nitrogen cancentrations, the preferential accumulation of $\mathrm{C}$ hordein polypeptides takes place irrespective of whether the nitrogen is supplied continuously during the 14 day period or only during the last five days prior to harvest (Figure 2C).

The alcohol soluble translation products obtained by using endosperm polyadenylated RNA as template in the rabbit reticulocyte protein synthesizing system is shown in Figure 2, lower panel. Increasing amounts of polyadenylated RNA were tested in the translation system to determine the optimal concentration for incorporation of ${ }^{35} \mathrm{~S}$-methionine into protein. The mRNAs which responded most to the increasing nitrogen concentration are those encoding the $C$ hordein precursors. The B hordein mRNAs show a smaller increase in response to higher nitrogen concentration as judged from the in vitro synthesis of these precursor polypeptides. This indicates that the amount of translatable $\mathrm{C}$ hordein mRNA increases more than the mRNA coding for B hordein. The amount of translatable $\mathrm{C}$ hordein $\mathrm{mRNA}$ at high nitrogen concentrations is comparable at 15 and 22 days after anthesis (Figure 2A and B). Late application of nitrogen (Figure $2 \mathrm{C}$ ) enhances the amount of both $\mathrm{B}$ and $\mathrm{C}$ hordein mRNAs although to a lower level than in endosperms that received nitrogen continuously (Figure 2B and C).

Figure 3 shows the dot hybridizations of a B1 hordein cDNA to different concentrations of total endosperm RNA. The amount of B hordein mRNA is low in endosperms cultured in the absence of nitrogen (Figure 3A, 3B). Culture of spikes in $0.5 \mathrm{~g} \mathrm{~N} \times \mathrm{l}^{-1}$ from eight days after anthesis resulted in a two fold increase in the amount of B hordein RNA (Figure 3A, B). Only a slight increase in the hybridization signal was observed for the RNAs from the highest

Figure 2. The effect of different supplies of nitrogen on the hordein polypeptide pattern and on the in vitro translatable hordein mRNA from developing Bomi endosperms.

Upper panel: Hordein polypeptides were extracted from developing barley endosperms with 55\% 2-propanol and 4mM-dithiothreitol. Protein corresponding to 0.01 endosperm (see Table 1) was separated by SDS-PAGE and detected by Coomassie-blue staining. Lower panel: Polyadenylated RNA was translated in a rabbit reticulocyte system containing ${ }^{35} \mathrm{~S}$-methionine. Aliquots containing 300,000 specific cpm were extracted with 55\% 2-propanol and analyzed by SDS-PAGE and fluorography. The position of $\mathrm{C}$ and $\mathrm{B}$ hordein polypeptides are indicated by hor Cand hor B, respectively. A. Spikes grown with the amount of nitrogen indicated from day 8 to day 15 after anthesis. B. Spikes grown with the amount of nitrogen indicated from day 8 to day 22 after anthesis. C. Spikes grown in absence of nitrogen until 17 days after anthesis, when they were supplied with the amounts of nitrogen indicated until harvest ( 22 days after anthesis). 
H. GIESE \& H.E. HoPP: Nitrogen nutrition and endosperm mRNA

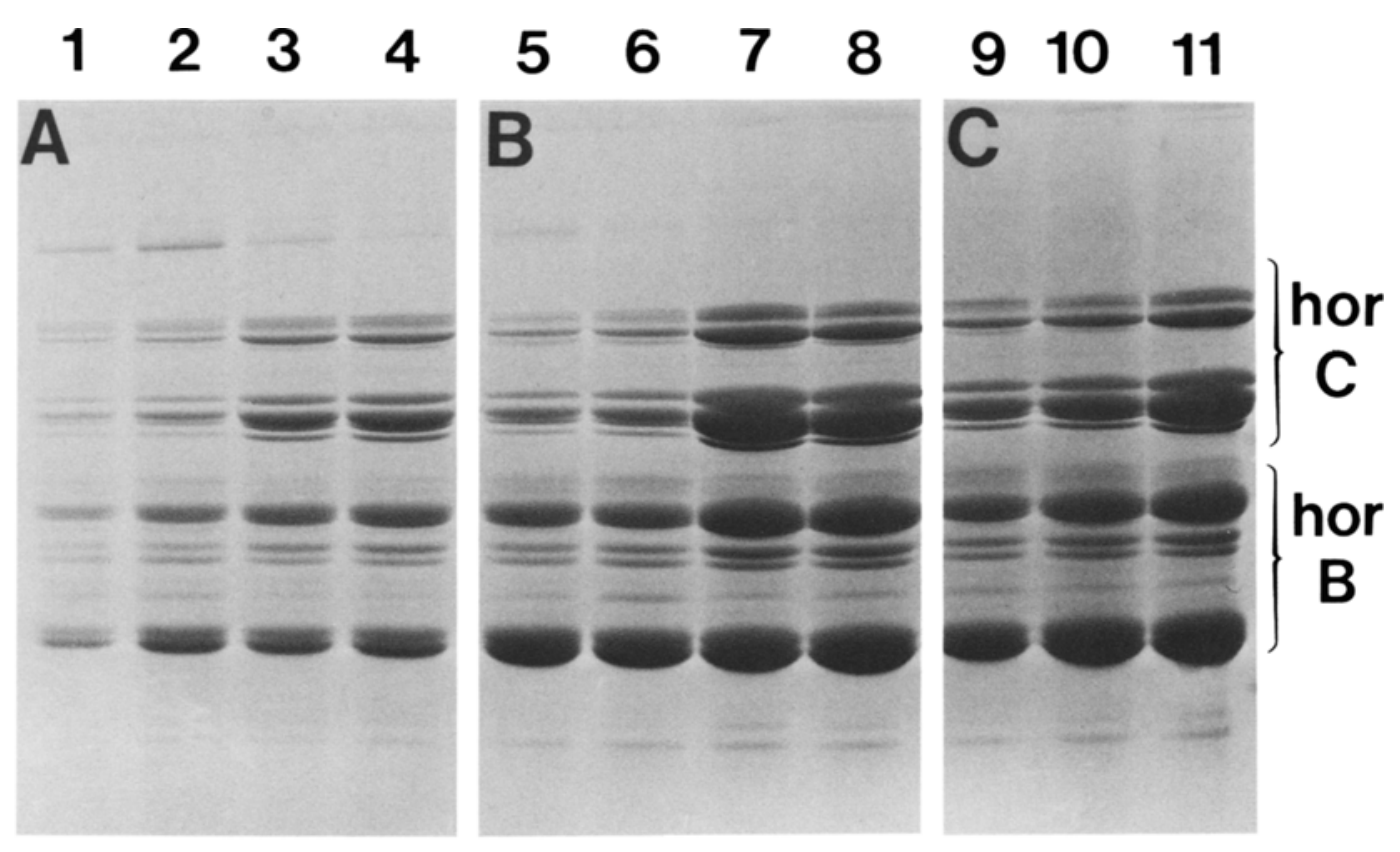

$\begin{array}{lllllllllll}1 & 2 & 3 & 4 & 5 & 6 & 7 & 8 & 9 & 10 & 11\end{array}$

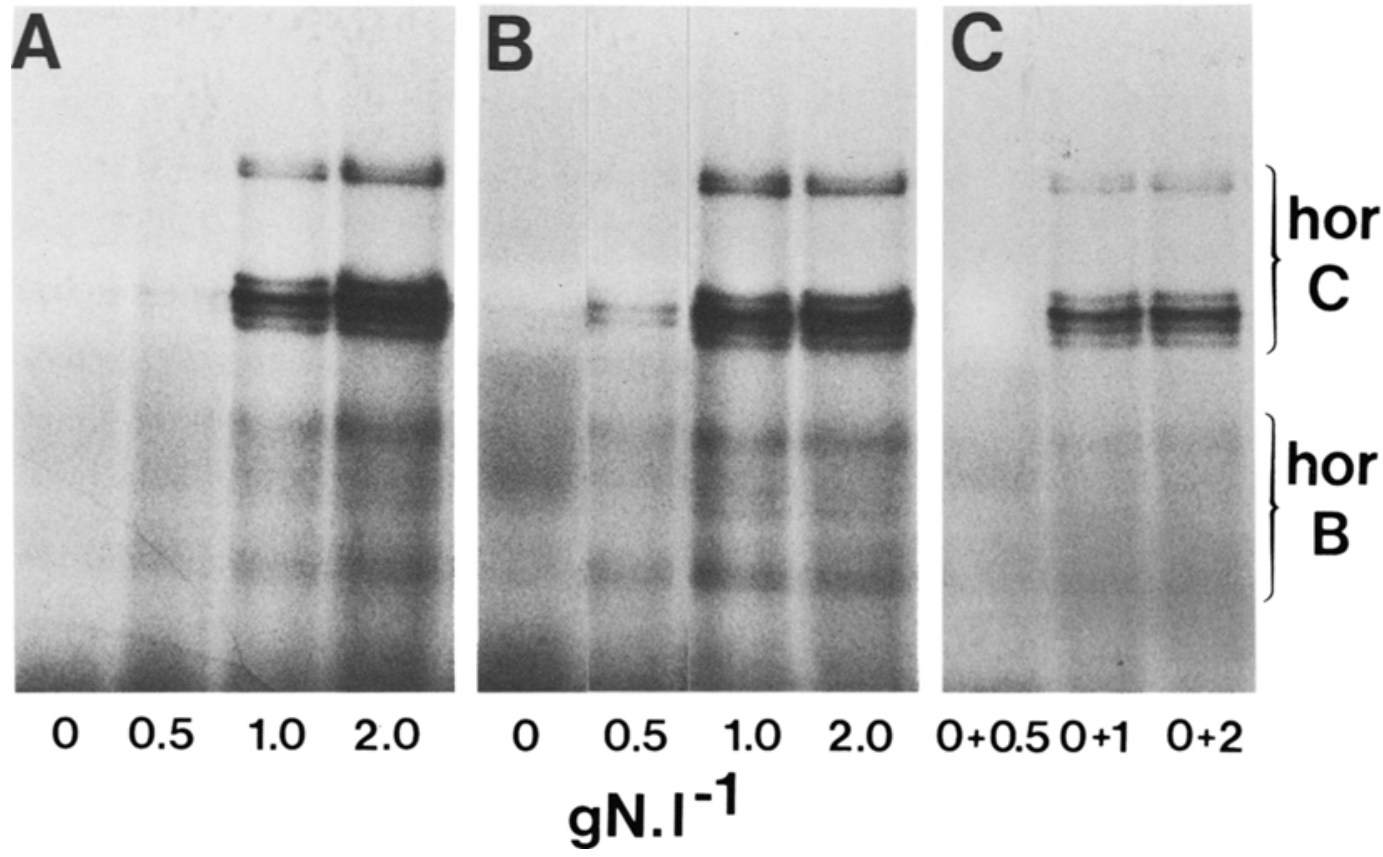



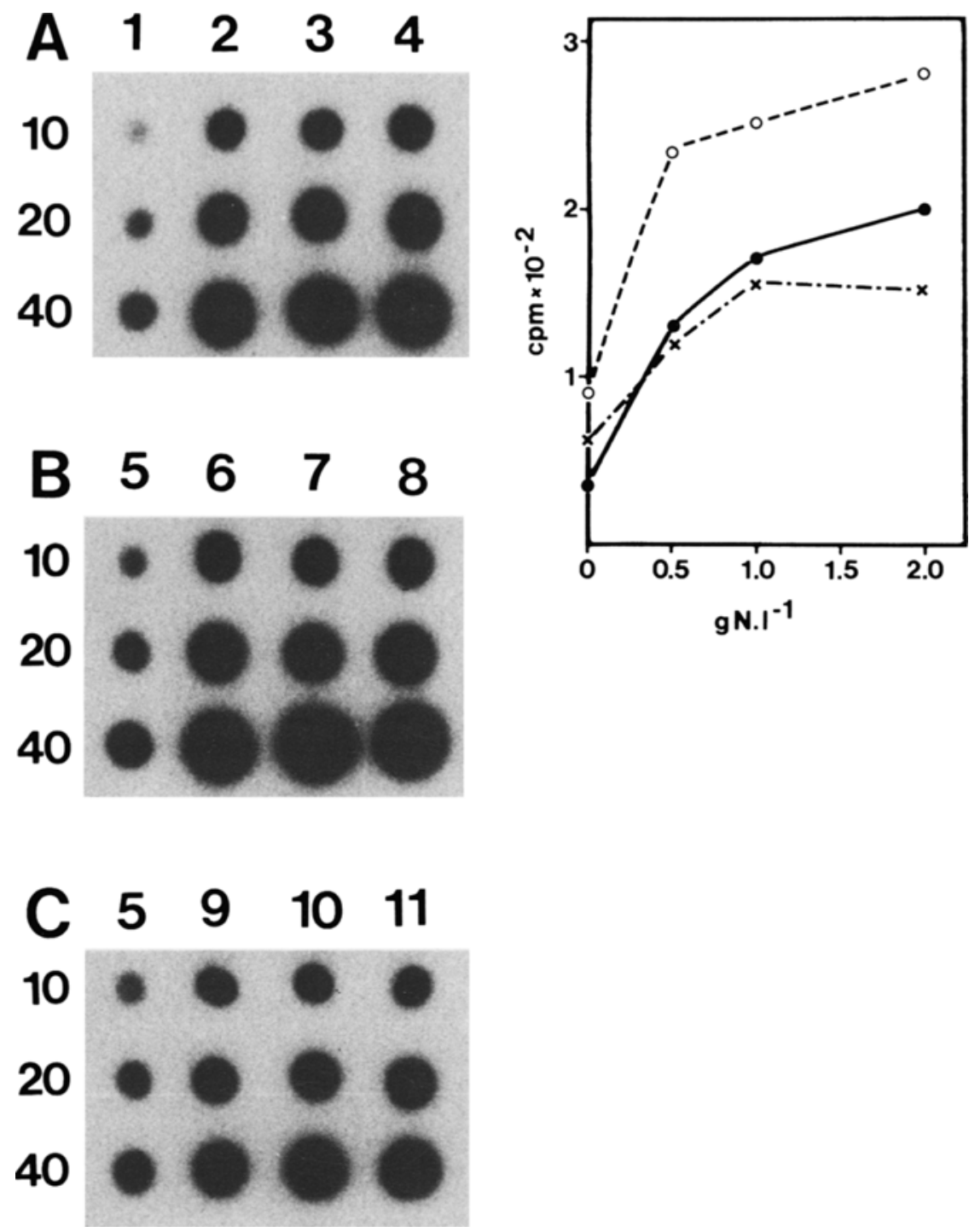

Figure 3. The effect of nitrogen supply on the amount of Bomi mRNA hybridizing to the cDNA probe (pc hor2-4) encoding the carboxyterminal portion of a B1 hordein polypeptide.

Amounts 10,20 and $40 \mu \mathrm{g}$, of Bomi endosperm RNA were applied to a nitrocellulose filter and hybridized to ${ }^{32} \mathrm{P}$-labelled $\mathrm{pc}$ hor $2-4 \mathrm{DNA}$ at $\mathrm{Tm}:-25^{\circ} \mathrm{C}$. The RNA complementary to the probe was detected by autoradiography. Dots were cut from the nitrocellulose filter and the hybridization quantitated by liquid scintillation counting. $\mathrm{A}=-, \mathrm{B}=\cdots, \mathrm{C}=\cdots \cdots \cdot \cdot \mathrm{A}, \mathrm{B}$ and $\mathrm{C}$ are as in Figure 2.

Figure 4. The effect of different supplies of nitrogen on the albumin, globulin and glutelin polypeptide pattern and on the in vitro translatable $\beta$-amylase and protein $\mathrm{Z}$ mRNAs from developing Bomi barley endosperms.

Upper panel: Polypeptides were extracted from developing barley endosperms with a buffer solution containing $1 \%$ SDS and 5mm-dithiothreitol. Protein corresponding to 0.01 endosperm (see Table I) was separated by SDS-PAGE and detected by Coomassie-blue staining. Polyadenylated RNA was translated in a rabbit reticulocyte system containing ${ }^{35} \mathrm{~S}$-methionine. Aliquots containing 400,000 specific $\mathrm{cpm}$ were immunoprecipitated with protein $Z$ (middle panel) and with $\beta$-amylase (lower panel) antibodies. Labelled polypeptides were analyzed by SDS-PAGE and fluorography. The positions of protein $Z$ and $\beta$-amylase are indicated by $Z$ and $\beta$,respectively. $A$, $B$ and $C$ are as in Figure 2. 
H. GIESE \& H.E. HOPP: Nitrogen nutrition and endosperm mRNA
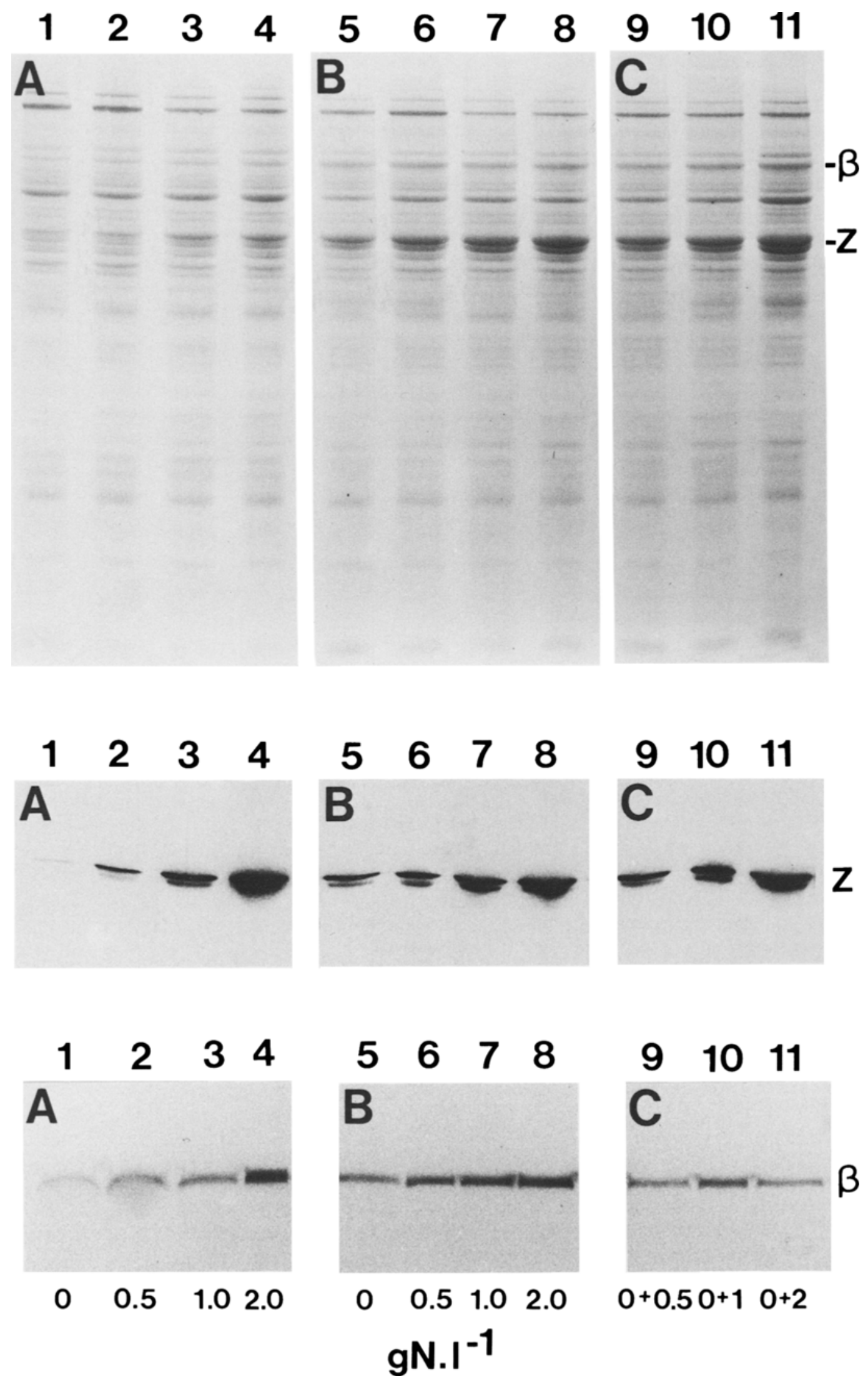

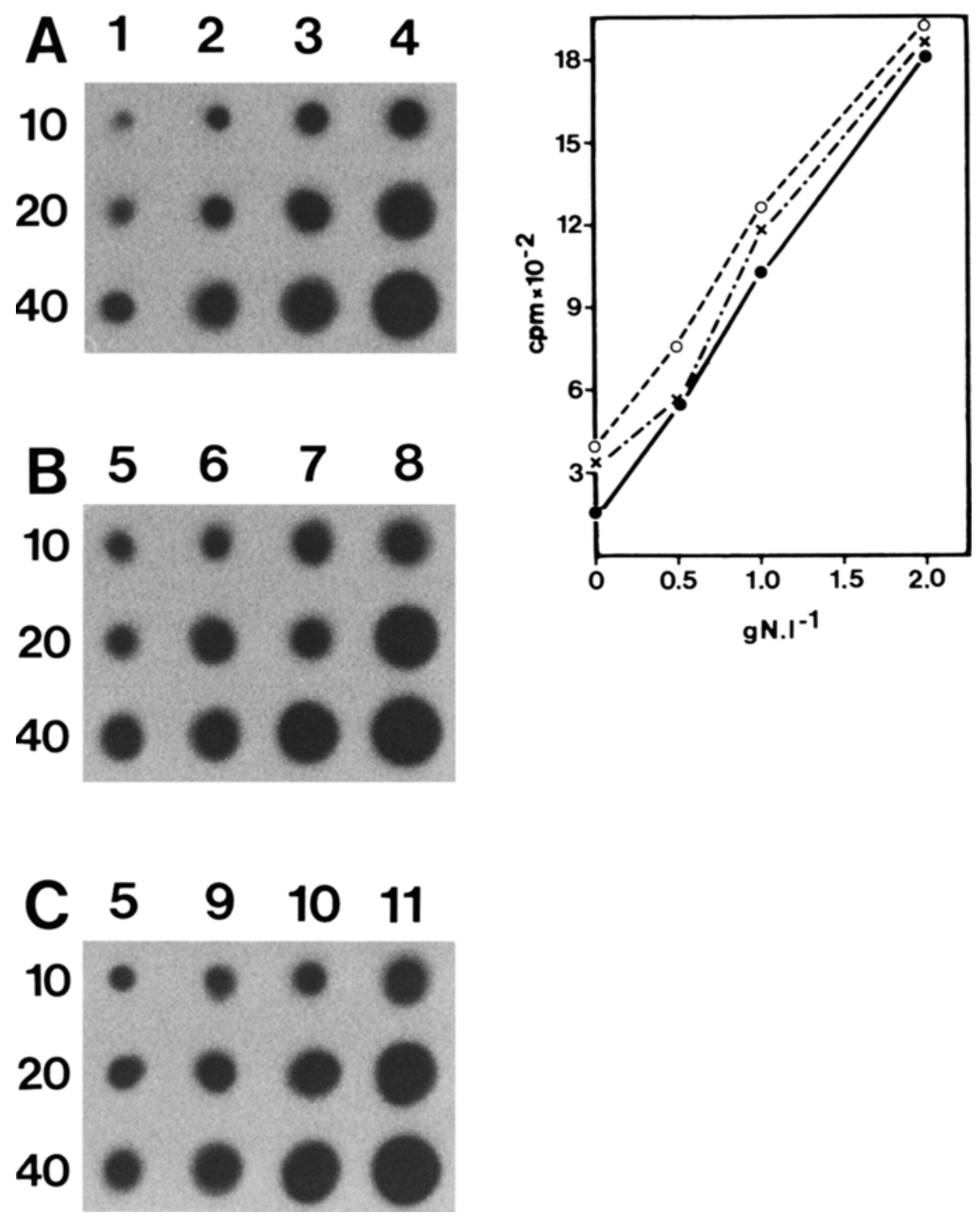

Figure 5. The effect of nitrogen supply on the amount of Bomi mRNA hybridizing to a cDNA probe encoding the amino-terminal portion of protein $Z$.

Amounts of 10,20 and $40 \mu \mathrm{g}$ of Bomi endosperm RNA were applied to a nitrocellulose filter and hybridized to ${ }^{32} \mathrm{P}$-labelled protein $\mathrm{Z}$ cDNA at $\mathrm{Tm}:-22^{\circ} \mathrm{C}$. The RNA complementary to the probe was detected by autoradiography. Dots were cut from the nitrocellulose filter and the hybridization quantitated by liquid scintillation counting. $A=-, B=--, C=-\cdots \cdot \cdot A, B$ and $C$ are as in Figure 2.

nitrogen treatments (Figure $3 \mathrm{~A}$, tracks 3 and 4). A similar hybridization pattern was observed at 22 days after anthesis (Figure 3B). Addition

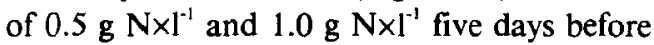
harvest to spikes cultured in the absence of nitrogen resulted in a two fold and three fold increase of the hybridizing $\mathrm{B}$ hordein $\mathrm{mRNA}$ (Figure $3 \mathrm{C}$ ). A further increase in the amount of $B$ hordein mRNA was obtained when the

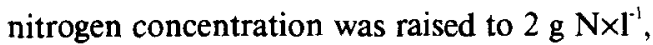
but without reaching the levels obtained by continuous nitrogen supply (Figure 3C). 

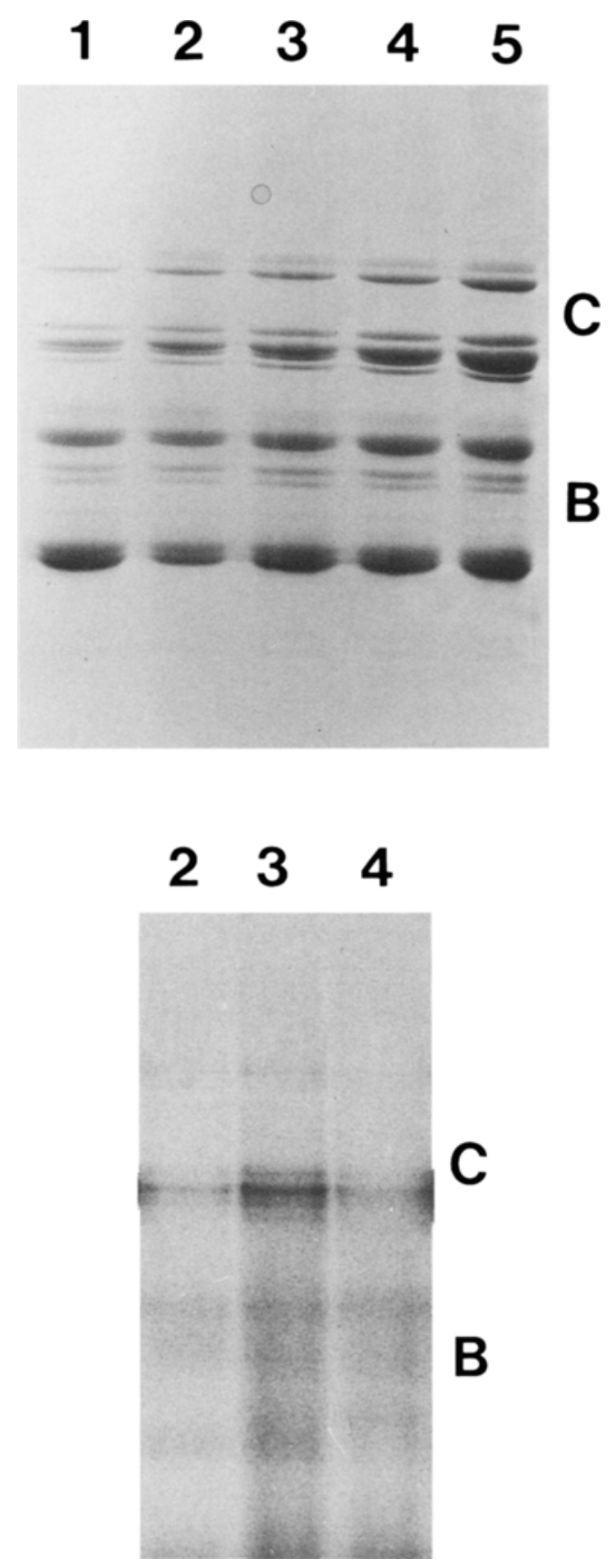

Figure 6. The effect of a three day pulse of $2 \mathrm{~g} \times \mathrm{l}^{-1}$ on the hordein polypeptide pattern and on the in vitro translatable hordein mRNA from Bomi endosperms (see Figure 1D).

Upper panel: Hordein polypeptides were extracted from endosperms. Protein corresponding to 0.01 endosperm was separated by SDS-PAGE and detected by Coomassie-blue staining. Lower panel: polyadeny-
SDS-PAGE of the individual polypeptides which were combined in the albumin, globulin and glutelin fraction shows a complex mixture of polypeptides (Figure 4). $\beta$-amylase and protein $\mathrm{Z}$ have previously been identified by comigration with purified polypeptides and by immunological techniques $(16,17,18,19)$. Protein $\mathrm{Z}$ is a family of polypeptides with slightly different molecular weight around 40,000 daltons (18) and $\beta$-amylase is a single polypeptide of 58,000 daltons (19). $\beta$-amylase and protein $Z$ are present in low amounts in 15 days old Bomi endosperms grown without nitrogen (Figure 4A, track 1). By 22 days after anthesis these proteins have increased and protein $\mathrm{Z}$ polypeptides have become the major protein components of the fraction (Figure 4B, track 5). Protein $\mathrm{Z}$ is increased linearly with elevating amounts of nitrogen in the media, while neither $\beta$-amylase, nor any of the other polypeptide components of the fraction show a response comparable to that of protein Z (Figure 4). Late application of nitrogen (Figure 1C) also elicits an increase in protein $\mathrm{Z}$ accumulation, while $\beta$-amylase content only is increased slightly (Figure $4 \mathrm{C}$ ).

The immunoaffinity isolated protein $\mathrm{Z}$ and $\beta$-amylase precursors synthesized in vitro by polyadenylated RNA from Bomi endosperms cultured at different nitrogen concentrations are shown in Figure 4 middle and lower panels. Low amounts of protein $\mathrm{Z}$ precursor polypeptides were detected in the translationproducts of RNA from endosperms cultivated in the absence of nitrogen (Figure 4A, track 1 and Figure 4B, track 5). Increasing concentrations of nitrogen in the media led to an increase in the amount of translatable protein $\mathrm{Z}$ mRNAs (Figure $4 \mathrm{~A}$ and

lated RNA was translated in a rabbit reticulocyte lysate. Aliquots containing 100,000 specific cpm were extracted and analyzed by SDS-PAGE and fluorography. Positions of $\mathrm{B}$ and $\mathrm{C}$ hordein polypeptides are indicated by B and C. Track 1: Spikes grown in the absence of nitrogen until harvest (25 days after anthesis). Tracks 2 - 4: Spikes harvested three, five and nine days after a $2 \mathrm{~g} \mathrm{~N} \times l^{-1}$ pulse (at 13 - 19 days after

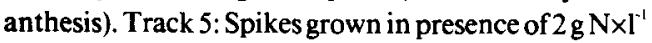
from 13 days after anthesis until harvest at 25 days after anthesis. 

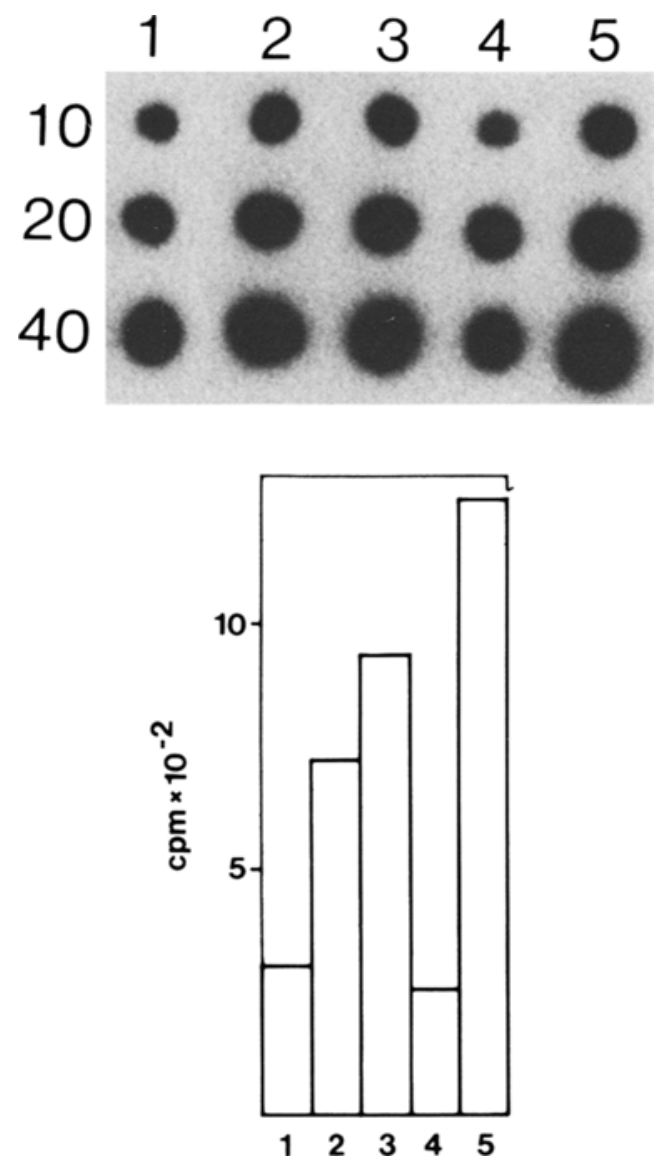

Figure 7. The effect of a three day pulse with $2 \mathrm{~g} \times \mathrm{I}^{-1}$ nitrogen on the amount of Bomi mRNA hybridizing to a B hordein cDNA probe.

Total RNA from spikes which grew in the absence of nitrogen except for a nitrogen pulse at 13 to 16 days after anthesis, was applied to a nitrocellulose filter, hybridized and detected by autoradiography. Dots were cut from the nitrocellulose filter and the hybridization quantitated by liquid scintillation counting. Spikes were harvested at 19 (row 2), 21 (row 3) and 25 days (row 4) after anthesis. The control hybridizations were carried out with total RNA isolated from spikes which grew in absence of nitrogen until 25 days after anthesis (row 1) and spikes which grew in presence of $2 \mathrm{~g} \mathrm{~N} \times \mathrm{I}^{-1}$ from 13 to 25 days after anthesis (row 5).

B). Comparable amounts of protein $\mathrm{Z}$ mRNAs could be reached by late application of nitrogen (Figure $4 \mathrm{C}$ ). The amount of translatable mRNA encoding for the $\beta$-amylase precursor shows an increase in response to increased amounts of nitrogen in the media (Figure $4 \mathrm{~A}$ and $\mathrm{B}$ ). In young endosperms cultured at low nitrogen levels $\beta$-amylase is lower than in older endosperms (Figure 4A, tracks 1 and 2 and Figure $4 B$, tracks 5 and 6 ). At the highest nitrogen level the amount of $\beta$-amylase mRNA appears similar at the two stages of development (Figure 4A, track 4 and Figure $4 B$, track 8 ). Late application of nitrogen did not lead to the amounts of $\beta$-amylase mRNA obtainable by continuous nitrogen supply (Figure 4C).

Dot hybridizations of a protein $\mathrm{Z}$ cDNA to different concentrations of total RNA from Bomi endosperms are displayed in Figure 5. As in the case of the B hordein mRNA the amount of hybridizing protein $\mathrm{Z}$ mRNA is low in spikes cultured in the absence of nitrogen (Figure 5A, row 1, Figure 5B, row 5). Culture of Bomi spikes in the presence of increasing amounts of nitrogen resulted in a linear increase of the level of protein $\mathrm{Z}$ mRNA (Figure 5A). This amounted to a six fold increase at the highest nitrogen concentrations. Late applications of nitrogen (Figure 1C) elicit an increase in the hybridization intensity (Figure 5C), comparable to that produced by continuous supply of nitrogen (Figure 5B). Comparable hybridizations signals were obtained using polyadenylated RNA.

\subsection{Spikes receiving a short nitrogen pulse}

The accumulation pattern of hordein polypeptides from endosperms at different times after they had received a high nitrogen supply for a short period is shown in Figure 6. For comparison, the accumulation pattern of 25 day old endosperms grown with (track 5) and without (track 1) nitrogen were included. An increase in all hordein polypeptides was observed over the period studied (Figure 6 , tracks 2, 3, 4). In the 25 day old endosperm that had received the nitrogen pulse (Figure 6, track 4) there is more $C$ hordein present than in endosperms cultured in the absence of nitrogen (track 1). The $\mathrm{C}$ hordein level, however, is lower than in endopsperms that received nitrogen until harvest (Figure 6 , tracks 4,5 ).

The amounts of translatable hordein mRNA in the endosperms cultured for a short period at high nitrogen levels (Figure $1 D$ ) is shown in the lower panel of Figure 6. A three days period 

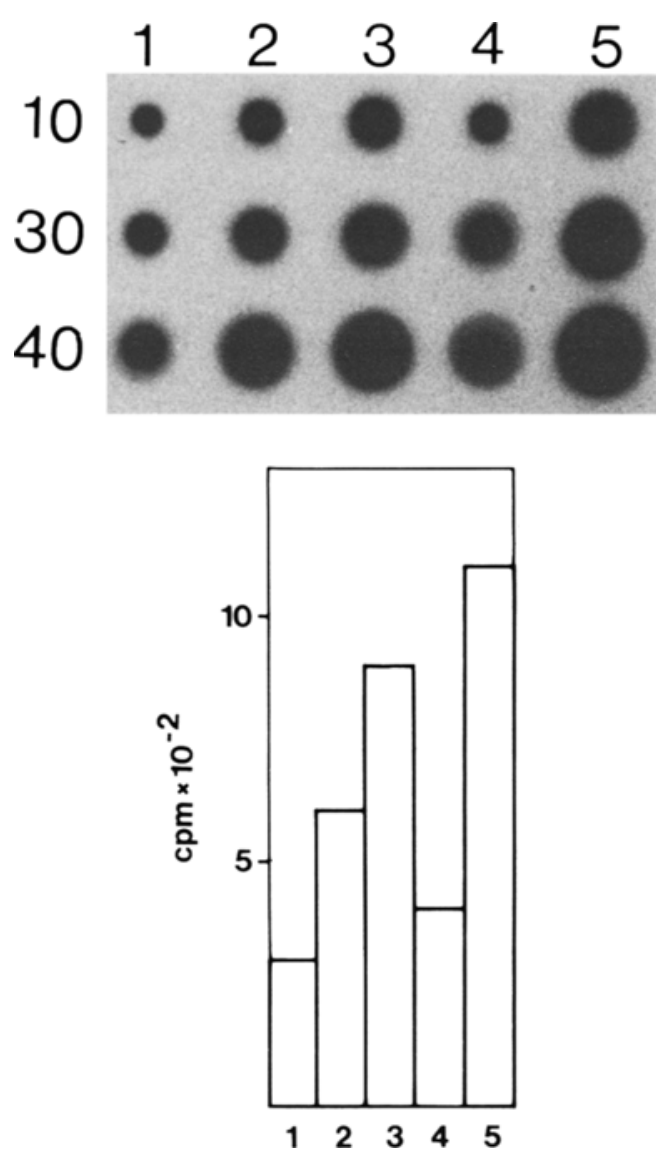

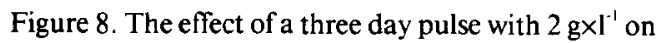
the amount of Bomi mRNA hybridizing to a protein $\mathrm{Z}$ cDNA probe.

Total RNA from spikes which grew in absence of nitrogen except for a period of three days at $2 \mathrm{~g} \mathrm{~N}^{-1}{ }^{-1}$ (at 13 to 16 days after anthesis) was applied to a nitrocellulose filter, hybridized and detected by autoradiography. Dots were cut from the nitrocellulose filter and the hybridization quantitated by liquid scintillation counting. Row numbers are as in Figure 7.

of high nitrogen supply was sufficient to enhance the amounts of translatable mRNAs coding for $\mathrm{B}$ and $\mathrm{C}$ hordeins to levels comparable to that of endosperms which received intermediate to high nitrogen supply continuously (Figure 6, track 3 and Figure 2B, tracks 6 and 7). The highest amount of translatable hordein mRNA in the endosperms was reached five days after the nitrogen pulse (Figure 6, track 3 ) whereafter the amount of RNA had declined as seen 9 days after the pulse (Figure 6, track 4).
The amount of B hordein mRNA increased between three and five days after the exposure to the high nitrogen level (Figure 7, rows 2 and 3 ). This concentration of mRNA is lower than that of endosperms cultured in presence of nitrogen until harvest (Figure 7, rows 3 and 5). On the other hand, the amount of $B$ hordein mRNA had decreased at nine days after the nitrogen pulse to a level comparable to that of endosperms cultured in the absence of nitrogen (Figure 7, rows 1 and 4).

The concentration of protein $\mathrm{Z}$ mRNA in endosperms cultured without nitrogen for 25 days is low (Figure 8, row 1). When $2 \mathrm{~g} \mathrm{~N} \times \mathrm{l}^{-1}$ are included in the medium a four fold increase in the level of protein $\mathrm{Z}$ mRNA was found (Figure 8 , row 5). Inclusion of high nitrogen in the media for three days resulted in elevated hybridization signals. The highest level of protein $Z$ mRNA was found five days after the nitrogen pulse. Endosperms harvested nine days after the pulse only contained one fourth of the amount of protein $\mathrm{Z}$ mRNA present at five days, indicating that the stimulatory effect of nitrogen on the RNA concentration in the endosperm had ceased (Figure 8, row 4).

\subsection{Effect of nitrogen on the expression of the $C$ hordein, protein $Z$ and $\beta$-amylase genes in mutant Risø 56 endosperms}

Figure 9 shows the hordein polypeptide pattern of Risø 56 endosperms cultured at different nitrogen concentrations in the medium. This mutant is defective in the synthesis of $B$ hordein polypeptides (40) but the $C$ hordein polypeptides increase linearly in response to increased nitrogen supply. The alcohol soluble translation products of polyadenylated RNA only consist of $\mathrm{C}$ hordein polypeptides (Figure 9 lower panel) and the amount of translatable mRNA encoding for the $\mathrm{C}$ hordein polypeptides increases in response to increasing nitrogen concentration.

The albumin, globulin and glutelin polypeptide pattern of mutant Risø 56 in the upper panel of Figure 10 is similar to the pattern of Bomi endosperms (Figure 4). Protein $Z$ as well as $\beta$-amylase content increases with increasing amount of nitrogen in the medium. In vitro synthesized protein $\mathrm{Z}$ precursor polypeptides 

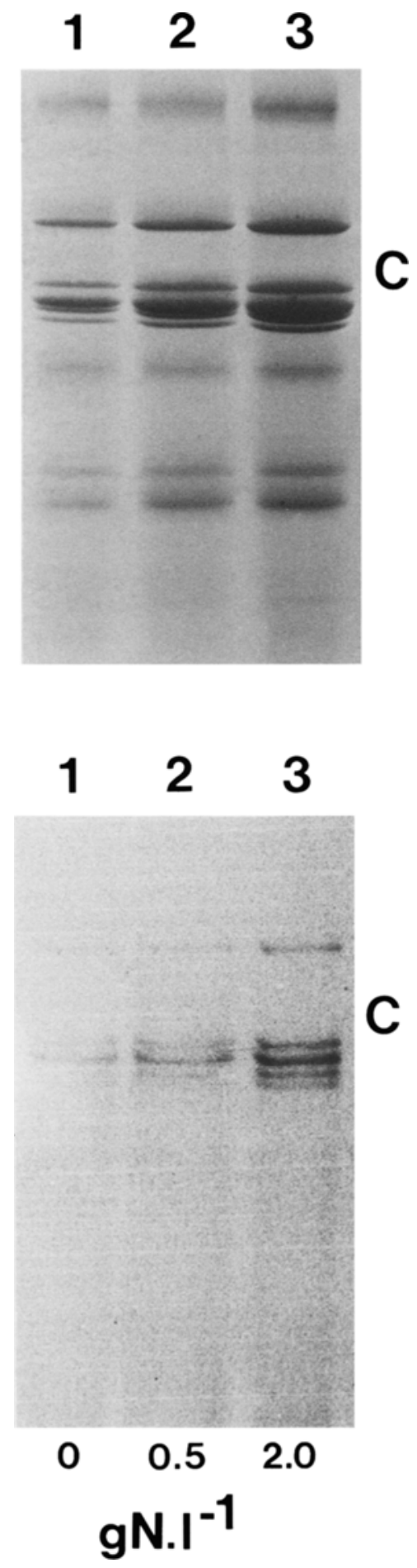

Figure 9. The effect of different supplies of nitrogen on the hordein polypeptide pattern and on in vitro translatable hordein mRNA from 19 days old endosperms of mutant Risø 56 (see Figure 1E).

Upper panel: Isopropanol extracted polypeptides were separated by SDS-PAGE and detected by Coomassie-blue staining. Protein corresponding to 0.02 of an endosperm (Table I) was applied in each slot. Lower panel: Polyadenylated RNA was translated in a rabbit reticulocyte system containing ${ }^{35} \mathrm{~S}$-methionine. Aliquots containing 50,000 specific $\mathrm{cpm}$ were extracted with 55\% 2-propanol and analyzed by SDS-PAGE and fluorography. The position of $C$ hordein polypeptides is indicated by a $\mathrm{C}$. The spikes were grown with the amount of nitrogen indicated.

were detected by immunoaffinity isolation among the translation products of Risø 56 mRNA using an antibody raised against the fraction $X$ of beer (38). Protein $Z$ is a major antigenic component of this fraction, although some cross-reactions to other in vitro translation products occur (Figure 10B). A drastic increase in the amount of protein $\mathrm{Z}$ mRNA was found in endosperms cultured at high nitrogen concentrations (Figure 10B). $\beta$-amylase precursor was detected by the same $\beta$-amylase antibody preparation used in the analysis of Bomi mRNA (Figure 10A). Weakly labelled polypeptides present in the tracks showing the $\beta$-amylase are probably due to carry over from the previous protein Z immunoaffinity isolation step. $\beta$-amylase $m R N A$ responds sharply to nitrogen at low nitrogen levels whereas the increase in the amount of $\beta$-amylase mRNA seems to be less pronounced at further elevation of nitrogen supply (Figure 10A).

Dot hybridizations of different concentrations of total RNA from Risø 56 endosperms to a protein $\mathrm{Z}$ cDNA probe are displayed in Figure 11 . The amount of protein $Z$ mRNA is low in spikes cultured in the absence of nitrogen (Figure 11, track 1). Culture of spikes in the presence of increasing concentrations of nitrogen resulted in an increase in the amount of protein $\mathrm{Z}$ mRNA (Figure 11, tracks 2, 3).

\section{DISCUSSION}

A controlled supply of nutrients to the barley endosperm during grain filling was obtained by 


\section{3}

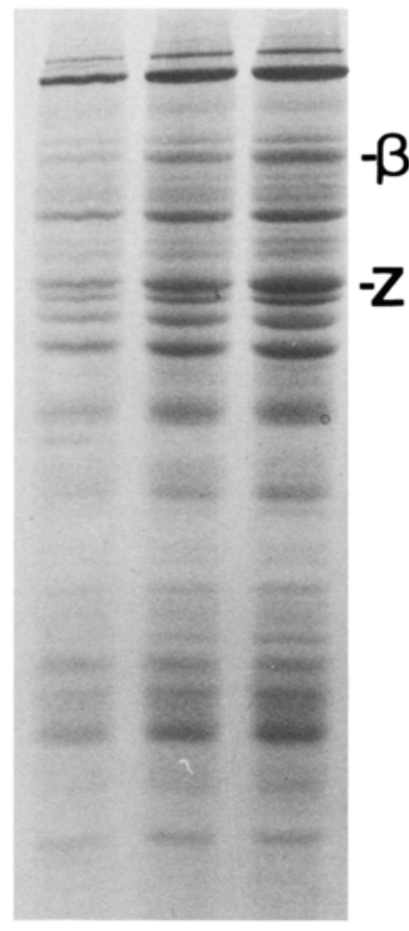

\section{$\begin{array}{llllll}1 & 2 & 3 & 1 & 2 & 3\end{array}$}

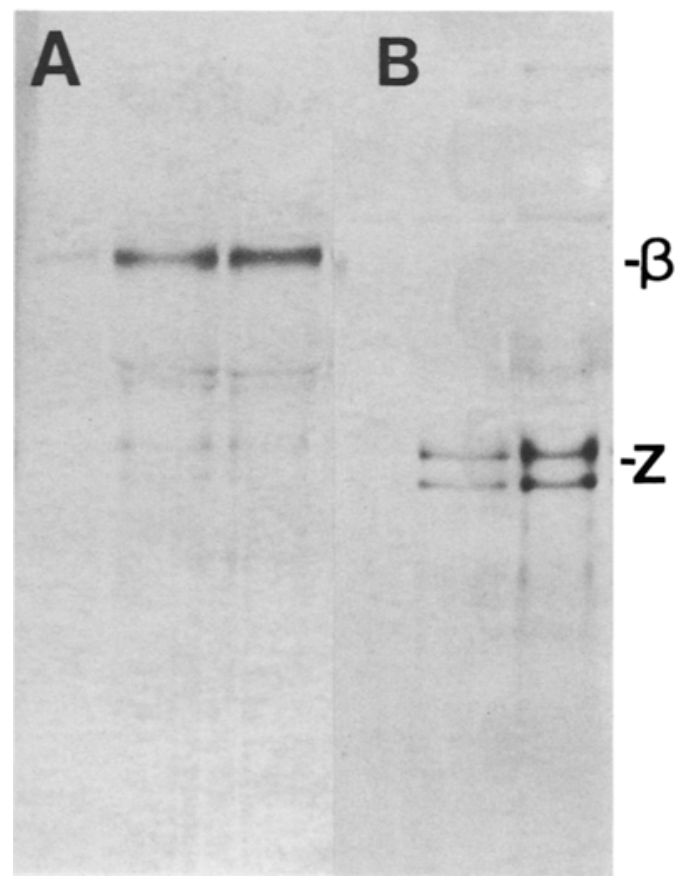

Figure 10. The effect of different supplies of nitrogen on the albumin, globulin and glutelin polypeptide pattern and on the in vitro translatable $\beta$-amylase and protein $\mathrm{Z}$ mRNAs from 19 day old endosperms of mutant Risø 56.

Upper panel: Polypeptides were extracted from developing Risø 56 endosperms with a buffer solution containing $1 \%$ SDS and 5mM-dithiothreitol. Protein corresponding to 0.02 endosperm (see Table I) was separated by SDS-PAGE and detected by Coomassieblue staining. Lower panel: Polyadenylated RNA was translated in a rabbit reticulocyte system containing ${ }^{33} \mathrm{~S}$-methionine. Aliquots containing 500,000 specific $\mathrm{cpm}$ were immunoprecipitated with $\beta$-amylase $(A)$ and protein $Z$ (B) antibodies and analyzed by SDS-PAGE and fluorography. $\beta$ stands for $\beta$-amylase precursor and $Z$ for protein $Z$ polypeptide. Tracks are as in Figure 9.

liquid culture. The syntheses of hordein, $\beta$-amylase and protein $\mathrm{Z}$ polypeptides have previously been found to increase with increasing concentrations of nitrogen in the culture medium (15, 16). The synthesis of $C$ hordein polypeptides and protein $\mathrm{Z}$ were stimulated more by application of nitrogen than the synthesis of $B$ hordein polypeptides. Using the spike culture system we examined the amount of $C$ hordein, protein $Z$ and $\beta$-amylase mRNA by in vitro translation and by molecular hybridization to cDNAs encoding a $\mathrm{B} 1$ hordein and a protein $\mathrm{Z}$ polypeptide, respectively.

Increasing the amounts of nitrogen in the medium resulted in an increase in the amount of these mRNAs (Figures 2, 3, 4 and 5). Nitrogen thus has either an effect on the transcription rate of the genes coding for protein $Z, \beta$-amylase and hordein polypeptides and/or slows the degradation of the respective mRNAs. This control acts similarly on $C$ hordein and protein $Z$ mRNA, as both continue to increase markedly with added nitrogen supply. $\beta$-amylase mRNA also increases in response to higher amounts of nitrogen but less drastically than $\mathrm{C}$ hordein and protein $\mathrm{Z}$ mRNAs. Nitrogen pulses during grain filling are little effective in enhancing $\beta$-amylase mRNA. The amount of $B$ hordein mRNAs increased at the lowest concentration of nitrogen while higher amounts of nitrogen only led to a slight further increase of the mRNA 

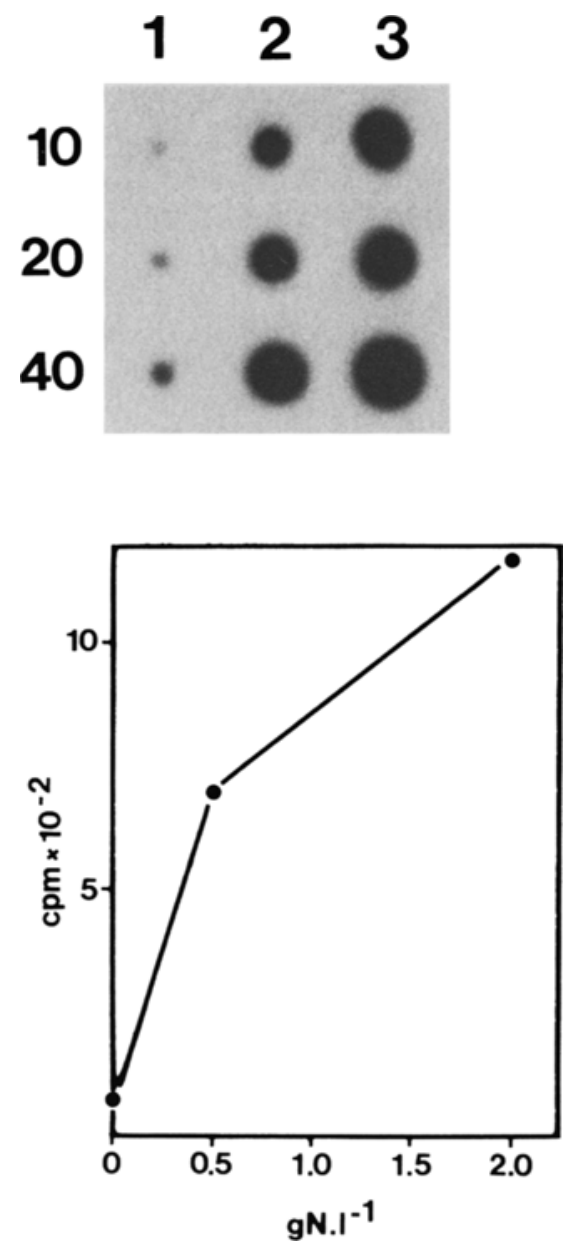

Figure 11. The effect of nitrogen nutrition on the amount of mutant Risø 56 RNA hybridizing to a protein Z cDNA probe.

Amounts of 10,20 and $40 \mu \mathrm{g}$ RNA from endosperms were applied to a nitrocellulose filter and hybridized to ${ }^{32} \mathrm{P}$-labelled protein $\mathrm{Z}$ cDNA at $\mathrm{Tm}:-22^{\circ} \mathrm{C}$. The RNA complementary to the probe was detected by autoradiography. Dots were cut from the nitrocellulose filter and the hybridization quantitated by liquid scintillation counting. Tracks are as in Figure 9.

(Figure 2, 3). This response is in contrast to that of the other mRNAs and suggests that nitrogen affects the expression of $B$ hordein genes differently, in agreement with in vivo labelling studies that revealed higher amounts of $\mathrm{C}$ hordein, compared to B hordein polypeptides at high nitrogen concentrations (15). The linear increase in the amount of $\mathrm{C}$ hordein and protein $\mathrm{Z}$ mRNA elicited by nitrogen dressing, and the inability to increase B hordein mRNA at the highest nitrogen concentrations, explains why protein $\mathrm{Z}$ and $\mathrm{C}$ hordein polypeptides act as the major storage proteins at high levels nitrogen.

Hordein and $\beta$-amylase have been shown to be synthesized on the membrane bound polysomes of barley endosperms $(3,24)$ while the site of synthesis of protein $Z$ remains to be determined. In the present study total endosperm polyadenylated RNA was used for in vitro translations and large amounts of protein $Z$ precursor polypeptides were identified among the the total translation products by immunoaffinity isolation. Although an increase in the level of $\beta$-amylase mRNA was observed as a consequence of nitrogen nutrition, total translation products indicate that the $\beta$-amylase mRNA is not abundantly represented in the total $\mathrm{mRNA}$ population. It is therefore unlikely that $\beta$-amylase can serve as a major nitrogen sink in Bomi endosperms.

Application of nitrogen after the commencement of hordein, protein $Z$ and $\beta$-amylase polypeptide synthesis produced an increase in the amount of mRNA encoding for these proteins (Figures 2C, 3, 4C and 5). It is possible to regulate the expression of hordein, protein $\mathrm{Z}$ and $\beta$-amylase genes after the onset of the synthesis period for these proteins while the late application of nitrogen does not allow the production of Bhordein and $\beta$-amylase mRNAs in amounts comparable to those found in endosperms cultured under continuous nitrogen supply (Figure 3 ,4). The protein $\mathrm{Z}$ mRNA can still reach the same concentration in the endosperm cell as when nitrogen is given continuously (Figure $6 \mathrm{C}$ ). By applying a short 3 day pulse of nitrogen to developing spikes it is possible to increase the level of hordein and protein $\mathrm{Z}$ mRNAs (Figure 6, 7, 8). Nine days after the nitrogen pulse was given the amount of mRNA has declined again as a result of the depletion of nitrogen in the endosperm, suggesting that gene expression can be switched on and off by the presence or the absence of nitrogen. This adds an example to those in which environmental factors have been found to induce and/or repress gene expression in plants (e.g. 13, 25, 36). The 
rather rapid differential change in expression of the investigated genes by short term nutrient supply is noteworthy.

In mutant Risø 56 endosperms, deficient in $B$ hordein polypeptide synthesis, the amount of $\mathrm{C}$ hordein, protein $\mathrm{Z}$ and $\beta$-amylase $\mathrm{mRNAs}$ increased as a result of increasing concentrations of nitrogen (Figures 9, 10 and 11). Since the analysis was done on plants grown under different conditions to that of Bomi, direct comparison of the amount of mRNA in the two genotypes cannot be made. However, the mutation does not appear to affect the stimulation of $C$ hordein, protein $Z$ and $\beta$-amylase gene expression upon nitrogen feeding. Protein $Z$ and $\beta$-amylase are known to be synthesized in high amounts in the high lysine barleys Hiproly and Risø $56(14,18,19)$ and it has been shown that in the case of Hiproly the amount of $\beta$-amylase mRNA is higher than in Bomi endosperms (24). It is therefore likely that the amount of protein $Z$ and $\beta$-amylase mRNA in Risø 56 at low nitrogen concentrations is higher than in Bomi. This might explain why the concentrations of $\beta$-amylase appears to increase in the polypeptide pattern of Risø 56 endosperms (Figure 10) while this is not the case in Bomi (Figure 4).

Apparently, the barley endosperm cell has the protein synthesizing capacity to carry out the increased polypeptide synthesis demanded at high nitrogen concentrations. This is suggested by the small change in the amount of total RNA (Table I) and the constant band intensity (Figure 5 ) in the molecular weight range expected to contain ribosomal polypeptides (5). Late applications of nitrogen (Figures 2C, 3, 4C, 5) and high nitrogen pulse experiments (Figures 6, 7 and 8 ) showed that induction of the protein synthesis was paralleled by an increase in the amount of mRNA. The apparently close relationship between concentration of mRNA and protein synthesis suggests that the regulatory mechanism is predominantly acting by changing the amount of mRNA. The effect of nitrogen on the amount of individual mRNA species could be due either to regulation of the rate of transcription, degradation, or to both. The short term (few days) changes in mRNA observed by pulsing with nitrogen is easiest understandable if mRNA turnover is constant and transcription enhanced or decreased. In order to investigate this point and to find the primary site of control on gene expression executed by nitrogen, the turn over rate of the individual mRNAs has to be determined.

\section{ACKNOWLEDGEMENTS}

The authors wish to express their appreciation to Dr. ANDERS BRA.NDT and to Professor DITER VON WETTSTEIN for discussions and help in the preparation of the manuscript. We are grateful to BENTE ANDERSEN for her excellent technical assistance and to NINA RASMUSSEN for making the diagrams. We are indebted to Dr. GEOFFREY FINCHER for his advice concerning the immunoprecipitation experiments as well as comments on the manuscript, to Dr. ANDERS BRANDT for his expertise concerning the in vitro translation experiments and to Dr. RICHARD Oliver and Dr. SøREN K. RASMUSSEN for reading the manuscript. $\mathrm{HEH}$ is indebted to $\mathrm{Dr}$. EWALD FAVRET for his continuous encouragement and support.

This research was supported by research contract No. GB 1-4-024-DK of the Biomolecular Engineering Programme of the Commission of the European Communities and by grant No. 460 of the Plant Protein Programme of the Commission of the European Communities.

\section{REFERENCES}

1. Blake. T.K.. S.E. UllRich \& R.A. Nilan: Mapping of the hor-3 locus encoding $D$ hordein in barley. Theor. Appl. Genet. 63, 367-371 (1982)

2. BRANDT. A. \& J. INGVERSEN: In vitro synthesis of barley endosperm proteins on wild type and mutant templates. Carlsberg Res. Commun. 41, 311 320 (1976)

3. BRANDT. A. \& J. INGVERSEN: Isolation and translation of hordein messenger RNA from wild type and mutant endosperm in barley. Carlsberg Res. Commun. 43, 451.469 (1978)

4. BRANDT. A..J. INGVERSEN. V.CAMMERON-MILLS, J.M. SChMitt \& S.K. Rasmussen: Molecular aspects of storage protein synthesis in barley endosperms. In Barley Genetcs IV. University of Edimburgh pp. 614-622 (1981)

5. Cameron-Mills, V. \& J. INGVersen: In vitro synthesis and transport of barley endosperm pro- 
teins: Reconstitution of functional rough microsomes from polyribosomes and stripped microsomes. Carlsberg Res. Commun. 43, 471-489 (1978)

6. Cameron-Mills, V. \& D. von Wettstein: Protein body formation in the developing barley endosperm. Carlsberg Res. Commun. 45, 577-594 (1980)

7. Chamberlain, J.P.: Fluorographic detection of radioactivity in polyacrylamide gels with the water-soluble fluor, sodium salicylate. Anal. Biochem. 98, 132-135 (1979)

8. Doll, H: A nearly non-functional mutant allele of the storage protein locus Hor 2 in barley. Hereditas 93, 217-222 (1980)

9. Doll, H.: Barley seed proteins and possibilities for their improvement. In: Seed Proteins. Biochemistry, Genetics, Nutritive Value (Eds. W. Gottschalk \& H. P. Müller), Martinus Nijhoff/ Dr. W. Junk Publishers, The Hague, pp. 207-224 (1983)

10. Doll, H. \& B. ANDERSEN: Preparation of barley storage protein, hordein, for analytical sodium dodecyl sulfate-polyacrylamide gel electrophoresis. Anal. Biochem. 115, 61-66 (1981)

11. Donovan, G.R. \& J.W. LeE: Growth of detached wheat heads in liquid culture. Plant Sci. Lett. 9, 107-113 (1977)

12. Faulks, A.J., P.R. Shewry \& B.J. Miflin: The polymorphism and structural homology of storage polypeptides (hordein) coded by the Hor- 2 locus in barley (Hordeum vulgare L.). Biochem. Genet. 19, 841-858 (1981)

13. Gerlach, W.L., A.J. Pryor. E.S. Dennis, R.J. FerL, M.M. Sachs \& W.J. Peacock: cDNA cloning and induction of the alcohol dehydrogenase gene (Adh 1) of maize. Proc. Natl. Acad. Sci. U.S.A. 79, 2981-2985 (1982)

14. GIESE, H. \& B. ANDERSEN: The course of protein synthesis during grain filling in normal and high lysine barley. Proc. Second Res. Coord. Meet. on Cereal Protein Improvement. I.A.E.A., Vienna 6-10 Dec. 1982 (in press)

15. GIESE, H., B. ANDERSEN \& H. DOLL: Synthesis of the major storage protein, hordein, in barley. Pulse-labeling study of grain filling in liquid-cultured detached spikes. Planta 159, 60-65 (1983)

16. Giese, H. \& J. HejgaARD: Synthesis of salt-soluble proteins in barley. Pulse-labelling study of grain filling in liquid cultured detached spikes. Planta (1984) in press

17. HejgaArd, J.: Free and protein-bound $\beta$-amylases of barley grain. Characterization by two-dimensional immunoelectrophoresis. Physiol. Plant. 38, 293-299 (1976)

18. HejgaARd. J.: Purification and properties of pro- tein Z - a major albumin of barley endosperm. Physiol. Plant. 54, 174-182 (1982)

19. HejgaARd, J. \& S. Boisen: High-lysine proteins in Hiproly barley breeding: Identification, nutritional significance and new screening methods. Hereditas 93, 311-320 (1980)

20. HoPP, H.E., S.K RasmusSen \& A. BRANDT: Organization and transcription of $B 1$ hordein genes in high lysine mutants of barley. Carlsberg Res. Commun. 48, 201-216 (1983)

21. HU,N.-T.\& J. MESsing: The making of strand-specific M13 probes. Gene 17, 271-277 (1982)

22. JENSEN, C.J.: Monoploid production by chromosome elimination. In: Applied and fundamental aspects of plant cell, tissue and organ culture, (J. Reinert \& Y. P. S. Bajaj, eds.) Springer, Berlin Heidelberg New York, pp. 299-330 (1977)

23. JeNSEN. J.. H.J. JøRGENSEN, H.P. JENSEN, H. Giese $\&$ H. Doll: Linkage of the hordein loci Hor 1 and Hor 2 with the powdery mildew resistance loci Ml-k and Ml-a on barley chromosome 5. Theor. Appl. Genet. 58, 27-31 (1980)

24. Jonassen, I., J. IngVersen \& A. Brandt: Synthesis of SP II albumin, $\beta$-amylase and chymotrypsin inhibitor $\mathrm{Cl}-1$ on polysomes from the endoplasmic reticulum of barley endosperm. Carlsberg Res. Commun. 46, 175-181 (1981)

25. KeY, J.L., C.Y. LIN \& Y.M. CHEN: Heat shock proteins in higher plants. Proc. Natl. Acad. Sci. U.S.A. 78, 3526-3530 (1981)

26. Kirkman, M.A.,P.R. SHEWRY \& B.J. MIFLIN: The effect of nitrogen nutrition on the lysine content and protein composition of barley seeds. J. Sci. Food Agric. 33, 115-127 (1982)

27. Kreis, M., S. Rahman, B.G. Forde, J. Pywell, P.R. SHEWRY \& B.J. MifLIN: Sub-families of hordein mRNA encoded at the Hor 2 locus of barley. Mol. Gen. Genet. 191, 194-200 (1983)

28. KREIS, M., P.R. SHEWRY, B.G. Forde, S. RAHMAN \& B. MifLIN: Molecular analysis of a mutation conferring the high-lysine phenotype on the grain of barley (Hordeum vulgare). Cell 34, 161-167 (1983)

29. KøIE, B., J. IngVersen, A.J. ANDERSEN, H. DOLL \& B.O. EGGUM: Composition and nutritional quality of barley protein. In: Evaluation of seed protein alterations by mutation breeding, IAEA Vienna pp. 55-61 (1976)

30. LEW,E.J.L. \& D.D. KASARDA: Structural homology of storage proteins coded by the Hor-1 locus of barley (Hordeum vulgare L.). Planta 153, 246-253 (1981)

31. Nielsen, G., H. Johansen, J. Jensen \& J. HejGAARD: Localization in barley chromosome 4 of genes coding for $\beta$-amylase (Bmy l) and protein 
Z(Paz 1). Barley Genet. Newslett. 13,55-57 (1983)

32. Rahman. S. P.R. Shewry. B.G. Forde. M. Kreis \& B.J. MIfLIN: Nutritional control of storage protein synthesis in developing grain of barley (Hordeum vulgare L.). Planta 159, 366-372 (1983)

33. Rasmlssen. S.K.. H.E. Hopp \& A. BRandT: Nucleotide sequences of $\mathrm{CDNA}$ clones for $\mathrm{B} 1$ hordein polypeptides. Carlsberg Res. Commun. 48, 187199 (1983)

34. Rasmussen, S.K. H.E. Hopp. A. Brandt. I. SVEnIDSEN \& J. HEJGaARd: Identification of a cDNA clone for protein $Z$, a major barley endosperm albumin. Carlsberg Res. Commun. 49. 385-390 (1984)

35. Sanger. F.. A.R. Coulson, B.G. Barrell., A.J. SMITH \& B.A. ROE: Cloning in single-stranded bacteriophage as an aid to rapid DNA sequencing. J. Mol. Biol. 143, 161-178 (1980)

36. SCandalios. J.G. \& J.A. Baum: Regulatory gene variation in higher plants. In: Advances in Genetics Vol.21 (Ed. E. W. Caspari) Academis Press, New York pp. 347-366 (1982)
37. Shewry, P.R.. A.J. Faulks, R.A. Pickering, I.T Jones. R.A. FinCH \& B.J. MifLIN: The genetic analysis of barley storage proteins. Heredity 44 . 383-389 (1980)

38. Shewry, P.R., R.A. Finch, S. Parmar. J. FrankLIN \& B.J. MIFLIN: Chromosomal location of hor 3 , a new locus governing storage proteins in barley. Heredity 50, 179-189 (1983)

39. SøRfNSE.N. S.B.\& M. OtTesen: Fractionation and characterization of beer proteins. Carlsberg Res. Commun. 43, 133-144 (1978)

40. Solari. R.M. \& E.A. Favret: Polymorphism in endosperm proteins of barley and its genetic control. In: Proc. 2 Int. Barley Genet. Symp. Ed. R. Nilan, Washington State Univ. Press pp. 23-31 (1971)

41. WetTStein. D. von: Genetic engineering in the adaptation of plants to evolving human needs. Experientia 39, 687-713 (1983) 